NOTES

\title{
Synthesis of Poly(1,3,4-oxadiazole)s by Direct Polycondensation of Bisamidrazones with Dicarboxylic Acids Using Phosphorus Pentoxide/Methanesulfonic Acid
}

\author{
Mitsuru UEDA and Mitsuo ODA \\ Department of Polymer Chemistry, Faculty of Engineering, \\ Yamagata University, Yonezawa, Yamagata 992, Japan \\ (Received September 10, 1988)
}

KEY WORDS Poly(1,3,4-oxadiazole) / Amidrazone / $N$-Acylamidrazone /

Dicarboxylic Acid/Condensing Agent /

Our studies on the synthesis of condnesation polymers by the direct polymerization in phosphorus pentoxide/methanesulfonic acid (PPMA) in a weight ratio of $1: 10$ have revealed that PPMA is a suitable condensing agent and solvent for the preparation of poly(ketone)s, poly(ether-sulfone)s and heterocyclic polymers. ${ }^{1}$

In order to extend the preparative utility of this method, we examined the reaction of amidrazones with carboxylic acids in PPMA and found a new method for the synthesis of 1,3,4-oxadiazoles. Poly(1,3,4-oxadiazole)s have already been synthesized from $\operatorname{poly}(N$ acylamidrazone)s, obtained from the polycondensation of bis(amidorazone)s and diacid chlorides. ${ }^{2}$

This article describes a successful synthesis of poly(1,3,4-oxadiazole)s by the direct poly condensation of dicarboxylic acids with isophthalamidrazone using PPMA.

\section{EXPERIMENTAL}

\section{Materials}

The reagent PPMA was prepared according to the reported procedure. ${ }^{3}$ Various substituted benzoic acids $\mathbf{2 a}-\mathbf{2 d}$ of reagent grade were used as received. Benzamidrazone (1) and isophthalamidrazone (5) were prepared from the corresponding nitrile compounds in two steps by the reported procedure. ${ }^{4} 4,4^{\prime}$-Oxybisbenzoic acid (8a), 3,3'-( p-phenylenedioxy)dibenzoic acid (8b), and 4,4'-(p-phenylenedioxy)dibenzoic acid (8c) were prepared through oxidation of the corresponding dimethyl compounds with potassium permanganate in pyridine-water. These dicarboxylic acids were purified by recrystallization. 8a: mp $337^{\circ} \mathrm{C}$ (by DTA) (lit. ${ }^{5} 331-333^{\circ} \mathrm{C}$, from acetic acid), $8 \mathbf{b}: \mathrm{mp} 312^{\circ} \mathrm{C}$ (by DTA) (lit. ${ }^{6}$ $305-313^{\circ} \mathrm{C}$, from acetic acid), $8 \mathbf{c}: \mathrm{mp} 333^{\circ} \mathrm{C}$ (by DTA) (lit. ${ }^{6} 331-333^{\circ} \mathrm{C}$, from dioxane).

\section{Model Reaction}

Typical example is as follows:

$N$-Benzoylbenzamidrazone (3a). A mixture of $1(0.135 \mathrm{~g}, 1.0 \mathrm{mmol})$ and $2 \mathrm{a}(0.122 \mathrm{~g}, 1.0$ mmol) in PPMA $(2 \mathrm{ml})$ was stirred at $60^{\circ} \mathrm{C}$ for $1 \mathrm{~h}$. The solution was poured into icewater $(150 \mathrm{ml})$, and neutralized with sodium carbonate. The product was filtered, washed with water and dried. The yield was $0.216 \mathrm{~g}$ $(90 \%)$. Recrystallization from ethanol produced white needles. mp $173-174^{\circ} \mathrm{C}$. The IR spectrum $(\mathrm{KBr})$ showed absorptions at $v$ $3200-3500(\mathrm{~N}-\mathrm{H}), 1680(\mathrm{C}=\mathrm{O})$, and 1640 $\mathrm{cm}^{-1}(\mathrm{C}=\mathrm{N})$. Anal. Calcd for $\mathrm{C}_{14} \mathrm{H}_{13} \mathrm{~N}_{3} \mathrm{O}$ : 
C, $70.28 \% ; \mathrm{H}, 5.48 \%$;, $17.56 \%$. Found: C, $70.11 \%$; H, $5.50 \%$; N $17.42 \%$.

$N$-(m-Nitrobenzoyl) benzamidrazone (3b). Recrystallization from ethanol gave yellow needles. mp 245-246 C. Anal. Calcd for $\mathrm{C}_{14} \mathrm{H}_{12} \mathrm{~N}_{4} \mathrm{O}_{3}$ : C, $59.15 \% ; \mathrm{H}, \quad 4.26 \% ; \quad \mathrm{N}$, $19.71 \%$. Found: C, $59.1 \%$; H, $4.3 \%$; N, $19.7 \%$.

$N$-(p-Methoxybenzoyl)benzamidrazone (3c). Recrystallization from ethanol gave white needles. mp $195-196^{\circ} \mathrm{C}$. Anal. Calcd for $\mathrm{C}_{15} \mathrm{H}_{15} \mathrm{~N}_{3} \mathrm{O}_{2}$ : C, $66.90 \% ; \quad \mathrm{H}, \quad 5.61 \% ; \quad \mathrm{N}$, $15.60 \%$. Found: C, $66.88 \%, \mathrm{H}, 5.41 \% \mathrm{~N}$, $15.30 \%$.

2,5-Diphenyl-1,3,4-oxadiazole (4a). 1 (0.135 $\mathrm{g}, 1.0 \mathrm{mmol})$ and $2 \mathrm{a}(0.122 \mathrm{~g}, 1.0 \mathrm{mmol})$ were dissolved in PPMA $(1 \mathrm{ml})$. The solution was stirred at $140^{\circ} \mathrm{C}$ for $1 \mathrm{~h}$. The product was isolated as described above. The yield was $0.194 \mathrm{~g}(87 \%)$. Recrystallization from ethanol produced white plates. mp $143-144^{\circ} \mathrm{C}$ (lit. $^{7}$ $\left.138^{\circ} \mathrm{C}\right)$. The IR spectrum showed absorptions at $v 1560(\mathrm{C}=\mathrm{N})$, and $1010 \mathrm{~cm}^{-1}(\mathrm{C}-\mathrm{O}-\mathrm{C})$.

$N, N^{\prime}$-Dibenzoylisophtalamidrazone (6a). A mixture of $5(0.192 \mathrm{~g}, 1.0 \mathrm{mmol})$ and $\mathbf{2 a}$ $(0.244 \mathrm{~g}, 2.0 \mathrm{mmol})$ in PPMA $(2.0 \mathrm{ml})$ was stirred at $60^{\circ} \mathrm{C}$ for $1 \mathrm{~h}$. The product was isolated as described above. The yield was $0.342 \mathrm{~g}$ $(86 \%)$. mp $215-216^{\circ} \mathrm{C}$. The IR spectrum showed absorptions at $3200-3400(\mathrm{~N}-\mathrm{H})$ and $1640 \mathrm{~cm}^{-1} \quad(\mathrm{C}=\mathrm{N})$. Anal. Calcd for $\mathrm{C}_{22} \mathrm{H}_{20} \mathrm{~N}_{6} \mathrm{O}_{2}$ : C, $65.99 \% ; \mathrm{H}, \quad 5.03 \% ; . \mathrm{N}$, $20.99 \%$. Found: C, $65.77 \%$; N $5.10 \%$; , $21.05 \%$.

$\cdot N, N^{\prime}$-Bis(m-nitrobenzoyl)isophthalamidrazone(6). Recrystallization from DMF produced yellow powder. mp $189-190^{\circ} \mathrm{C}$. Anal. Calcd for ${ }_{22} \mathrm{H}_{18} \mathrm{~N}_{8} \mathrm{O}_{6}:$ C, $53.88 \% ; \mathrm{H}$, $3.70 \%$; N, $22.85 \%$. Found: C, $53.67 \%$; H, $3.74 \%$; N, $22.27 \%$.

$N, N^{\prime}$-Bis( p-methoxybenzoyl )isophthalamidrazone (6c). Recrystallization from DMF gave white crystalls. mp $218-219^{\circ} \mathrm{C}$. Anal. Calcd for $\mathrm{C}_{24} \mathrm{H}_{24} \mathrm{~N}_{6} \mathrm{O}_{4}$ : C, $62.60 \%$; H, $5.25 \%$; $\mathrm{N}, 18.24 \%$. Found: C, $62.26 \%$; H, 5.13\%; N, $18.19 \%$.

2,2'-m-Phenylenebis(5-phenyl-1,3,4-oxa- diazole $)(7 \mathrm{a}) .5(0.192 \mathrm{~g}, 1.0 \mathrm{mmol})$ and $2 \mathrm{a}$ $(0.244 \mathrm{~g}, 2.00 \mathrm{mmol})$ were dissolved in PPMA $(2.0 \mathrm{ml})$. The solution was stirred at $140^{\circ} \mathrm{C}$ for $1 \mathrm{~h}$. The yield was $0.354 \mathrm{~g} \quad(97 \%)$. Recrystallization from DMF gave white powder. $\mathrm{mp} 252-253^{\circ} \mathrm{C}$. The IR spectrum showed absorptions at $1530(\mathrm{C}=\mathrm{N})$ and $1010 \mathrm{~cm}^{-1}$ (C-O-C). Anal. Calcd for $\mathrm{C}_{22} \mathrm{H}_{14} \mathrm{~N}_{4} \mathrm{O}_{2}$ : C, $72.12 \% ; \mathrm{H}, 3.85 \% ; \mathrm{N}, 15.29 \%$. Found: $\mathrm{C}$, $72.0 \% ; \mathrm{H}, 4.1 \% ; \mathrm{N}, 15.2 \%$.

$2,2^{\prime}$-m-Phenylenebis [5-( p-methoxyphenyl)1,3,4-oxadiazole] (7c). Recrystallization from DMF yielded a faint pink powder. mp 272$273^{\circ}$. Anal. Calcd for $\mathrm{C}_{24} \mathrm{H}_{18} \mathrm{~N}_{4} \mathrm{O}_{4}$ : C, $67.60 \%$; $\mathrm{H}, 4.25 \%$; N $13.14 \%$. Found: C, $66.50 \%$; $4.31 \% ; \mathrm{N}, 13.22 \%$.

$N, N^{\prime}$-m-Phenylenebis[5-(p-nitrophenyl)-1,3,4oxadiazole] (7d). Recrystallization from DMF gave yellow powder. mp $373^{\circ} \mathrm{C}$ (by DTA). Anal. Calcd for $\mathrm{C}_{22} \mathrm{H}_{12} \mathrm{~N}_{6} \mathrm{O}_{6}: \mathrm{C}$, $57.90 \% ; \mathrm{H}, 2.65 \%$;, $18.41 \%$. Found: C, $57.86 \% ; \mathrm{H}, 2.81 \% ; \mathrm{N}, 18.81 \%$.

\section{Polymer Synthesis}

Typical example of polymerization is as follows.

Polymer (9c) from (5) and (8c). A solution of $5(0.192 \mathrm{~g}, 1.0 \mathrm{mmol})$ and $8 \mathrm{c}(0.350 \mathrm{~g}$, $1.0 \mathrm{mmol})$ in PPMA $(2 \mathrm{ml})$ was stirred at $140^{\circ} \mathrm{C}$ for $16 \mathrm{~h}$. The resulting solution was poured into ice-water and neutralized with sodium carbonate. The polymer was collected, washed with hot water, and dried in vaccum at $100^{\circ} \mathrm{C}$ for $2 \mathrm{~d}$. The yield was essentially quantitative. The inherent viscosity of the polymer, in concentrated sulfuric acid was $0.30 \mathrm{dlg}^{-1}$ at $30^{\circ} \mathrm{C}$. The IR spectrum $(\mathrm{KBr})$ exhibited absorptions at $v 1550(\mathrm{C}=\mathrm{N})$ and $1000 \mathrm{~cm}^{-1}(\mathrm{C}-\mathrm{O}-\mathrm{C})$. Anal. Calcd for $\left(\mathrm{C}_{28} \mathrm{H}_{16} \mathrm{~N}_{4} \mathrm{O}_{4} \cdot 3 \mathrm{H}_{2} \mathrm{O}\right)_{n}$ : C, $63.88 \%$; H, $4.11 \%$; N, $10.64 \%$. Found: $\mathrm{C}$, $64.56 \%$; H, $3.71 \%$; N, $9.79 \%$.

\section{RESULTS AND DISCUSSION}

\section{Model Reaction}

The preparation of 1,3,4-oxadiazoles 
through intermediate $\mathrm{N}$-acylamidrazones has been known for many years. Cyclization of $N$ acylamidrazones leads to the formation of 1,2,4-triazoles or 1,3,4-oxadiazoles depending on the reaction conditions. Conversion of the amidrazones into triazoles takes place in basic solution, while the oxadiazoles are obtained in the presence of acid. ${ }^{8}$

To date, the synthesis of 1,3,4-oxadiazoles 4 by the reaction of amidrazones with carboxylic acids in PPMA has not been reported. Therefore, we first studied the reaction of benzamidrazone 1 with benzoic acid 2a over a

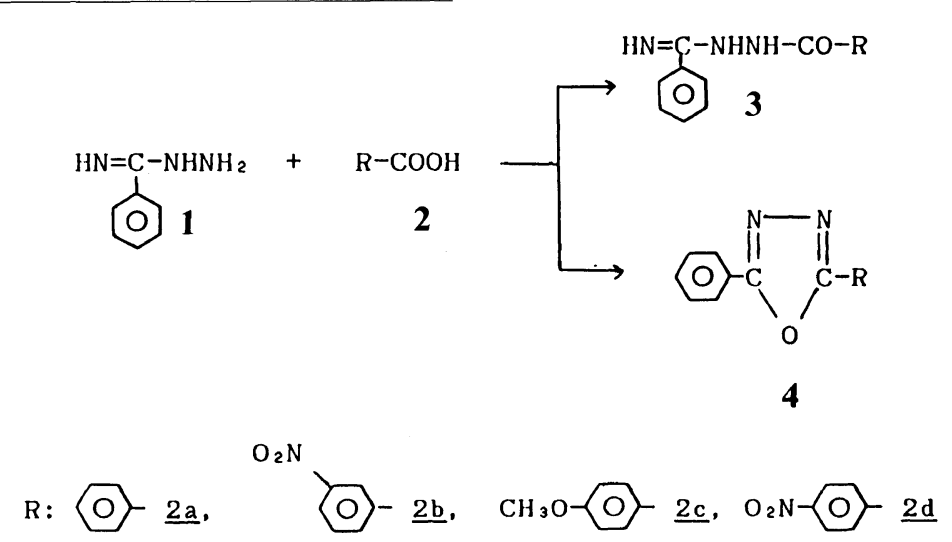

The results summarized in Table I indicate that 1 was easily acylated by benzoic acids containing electron donating goups and excellent yields of 4 were obtained. These findings of substituent effects of benzoic acids are explained as due to the stability of the reaction intermediates, acylium ions, as described in temperature range from $25^{\circ} \mathrm{C}$ to $140^{\circ} \mathrm{C}$. The reaction was performed by dissolving $\mathbf{1}$ and $\mathbf{2 a}$ in PPMA. After the reaction was completed, the solution was poured into ice-water and neutralized with sodium carbonate, and the crude product was filtered. These preliminary experiments showed that the condensation at $60^{\circ} \mathrm{C}$ for $1 \mathrm{~h}$ gave $N$-benzoylbenzamidrazone $3 \mathrm{a}$ and the reaction at $140^{\circ} \mathrm{C}$ for $1 \mathrm{~h}$ yielded 2,5-diphenyl-1,3,4-oxadiazole 4a.

On the basis of these results, various $N$ acylamidrazones 3 and 2,5-disubstituted-1,3,4oxadiazoles 4 were prepared (eq 1).

previous papers. ${ }^{1}$

Next, bifunctional model compound study was made to determine if the desired model compounds would be formed in quantitaive yields, essential for a polymer-forming reaction. The reaction of isophthalamidorazone 5 with 2 was studied in PPMA (eq 2)

Table I. Preparation of $N$-acylbenzamidrazones 3 and 2,5-diaryl-1,3,4-oxadiazoles 4 in PPMA ${ }^{\mathrm{a}}$

\begin{tabular}{|c|c|c|c|c|c|c|}
\hline \multirow{2}{*}{$\begin{array}{l}\text { Substituted } \\
\text { benzoic acid }\end{array}$} & \multicolumn{2}{|c|}{ Reaction conditions } & \multicolumn{4}{|c|}{ Product } \\
\hline & Temp $/{ }^{\circ} \mathrm{C}$ & $\mathrm{PPMA} / \mathrm{ml}$ & Type & Yield & $\mathrm{mp} /{ }^{\circ} \mathrm{C}$ & (lit.) \\
\hline $2 \mathbf{a}$ & 60 & 2.0 & $\mathbf{3 a}$ & 90 & $173-174$ & \\
\hline 2b & 60 & 2.0 & $\mathbf{3 b}$ & 22 & $245-246$ & \\
\hline $2 c$ & 60 & 2.0 & $3 c$ & 92 & $195-196$ & \\
\hline $2 a$ & 140 & 1.0 & $4 a$ & 87 & $143-144$ & $(138)^{7}$ \\
\hline $2 c$ & 140 & 1.0 & $4 c$ & 91 & $152-153$ & $(149-150)^{9}$ \\
\hline $2 d$ & 140 & 1.0 & $4 d$ & 67 & $228-229$ & $(207-208)^{9}$ \\
\hline
\end{tabular}

a Reaction was carried out with $1.0 \mathrm{mmol}$ of each reactant in PPMA for $1 \mathrm{~h}$. 


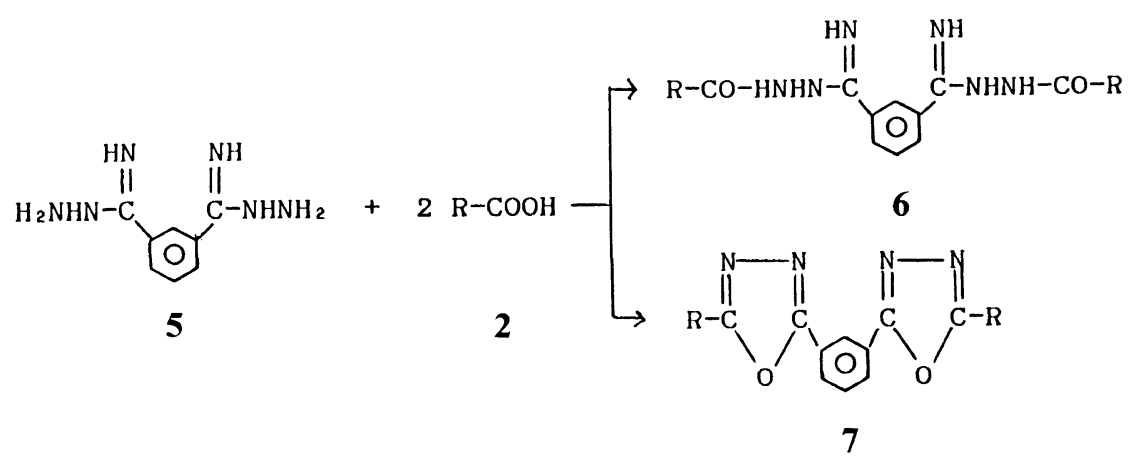

The results are summarized in Table II. Similar to the monofunctional model reaction, quantitative yields of the corresponding $N, N^{\prime}$ diacylisophthalamidroazones 6 and 2,2'-mphenylenebis(5-substituted-1,3-4-oxadiazole)s 7 were obtained from benzoic acid 2 having electron-donating groups at $60^{\circ} \mathrm{C}$ and $140^{\circ} \mathrm{C}$, respectively. The structures of new compounds 3, 4, 6, and 7 were determined by elemental analysis and IR spectroscopy.

\section{Polymer Synthesis}

On the basis of the model reactions, the direct polycondensation of 5 with aromatic dicarboxylic acids 8 was carried out in PPMA at $140^{\circ} \mathrm{C}$ (eq 3 ).
Table II. Preparation of $N, N^{\prime}$-diacylisophthalamidrazone 6 and 2,2'- $m$-phenylenebis $(5-$ aryl-1,3,4-oxadiazole)s 7 in PPMA $^{\mathrm{a}}$

\begin{tabular}{cccccc}
\hline \multirow{2}{*}{$\begin{array}{c}\text { Substituted } \\
\text { benzoic acid }\end{array}$} & Reaction & & \multicolumn{2}{c}{ Product } \\
\cline { 5 - 6 } \cline { 5 - 6 } \cline { 5 - 6 } & Temp $/{ }^{\circ} \mathbf{C}$ & & Type & Yield $/ \%$ \\
\hline 2a & 60 & & $\mathbf{6 a}$ & 86 \\
2b & 60 & & $\mathbf{6 b}$ & 31 \\
2c & 60 & & $\mathbf{6 c}$ & 95 \\
2a & 140 & & $\mathbf{7 a}$ & 97 \\
2c & 140 & & $\mathbf{7 c}$ & 99 \\
2d & 140 & & $\mathbf{7 d}$ & 89
\end{tabular}

a Reaction was carried out with $1.0 \mathrm{mmol}$ of 5 and 2 mmol of 2 in PPMA ( $2 \mathrm{ml})$ for $1 \mathrm{~h}$.
$\underline{5}+\mathrm{HOOC}-\mathrm{R}-\mathrm{COOH} \longrightarrow$

8<smiles>[R]/C(C)=N/N=C(/O)c1cccc(-c2nnc([3H])o2)c1</smiles>

9<smiles>[R]c1ccc(Oc2ccc([13CH3])cc2)cc1</smiles><smiles>Cc1ccc(Oc2ccccc2)cc1</smiles>

The results are listed in Table III. Poly $(1,3,4-$ oxadiazole) 9 was produced in quantitative yield with inherent viscosities up to $0.30 \mathrm{dl} \mathrm{g}^{-1}$.

The polymers were confirmed to be the proposed polymers 9 by comparing their IR spectra with those of the model compounds. The IR spectra showed characteristic absorptions around at 1550 and $1000 \mathrm{~cm}^{-1}$ charac-

teristic of the $\mathrm{C}=\mathrm{N}$ and $\mathrm{C}-\mathrm{O}-\mathrm{C}$ stretching, respectively. Elemental analysis also supported the formation of the expected polymers.

The polymers were brown solids and soluble in concentrated sulfuric acid, methanesulfonic acid, and $N$-methyl-2-pyrrolidone. The thermal stability of polymers 9 was examined by thermogravimetry (TG). A typical trace for 
Table III. Synthesis of poly(1,3,4-oxadiazole)s 9

\begin{tabular}{|c|c|c|c|c|c|}
\hline \multirow{3}{*}{$\begin{array}{c}\text { Dicar- } \\
\text { boxylic } \\
\text { acid }\end{array}$} & \multicolumn{2}{|c|}{ Reaction conditions } & \multicolumn{3}{|c|}{ Polymer } \\
\hline & Time & PPMA & & Yield & $\eta_{\mathrm{inh}}^{\mathrm{b}}$ \\
\hline & $\mathrm{h}$ & $\mathrm{ml}$ & & $\%$ & $\mathrm{dlg}^{-1}$ \\
\hline $8 \mathbf{a}$ & 67 & 2.0 & $9 \mathbf{a}$ & 99 & 0.21 \\
\hline $\mathbf{8 b}$ & 16 & 5.0 & 9b & 95 & 0.28 \\
\hline $8 c$ & 16 & 5.0 & $9 c$ & 99 & 0.30 \\
\hline
\end{tabular}

a Polycondensation was carried out with $1.0 \mathrm{mmol}$ of each monomer in PPMA at $140^{\circ} \mathrm{C}$.

b Measured at a concentration of $0.5 \mathrm{~g} \mathrm{dl}^{-1}$ in concentrated sulfuric acid at $30^{\circ} \mathrm{C}$.

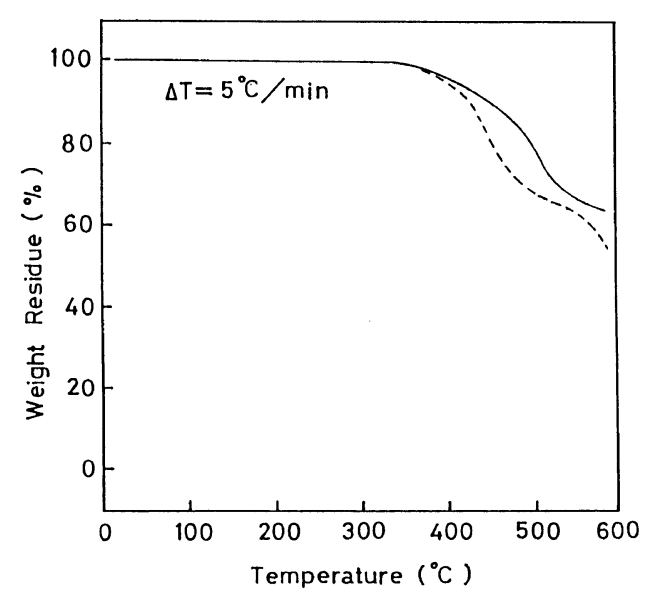

Figure 1. TG curves of polymer $9 c,(-)$ in nitrogen and (----) in air.

Table IV. Thermal stability of poly(1,3,4-oxadiazole)s 9

\begin{tabular}{cccc}
\hline Polymer & & \multicolumn{2}{c}{ Decomposition temp $/{ }^{\circ} \mathrm{C}^{\mathrm{a}}$} \\
\cline { 1 - 1 } \cline { 3 - 4 } Type & & In air & In nitrogen \\
\hline 9a & & 420 & 420 \\
9b & & 390 & 410 \\
9c & & 445 & 450 \\
\hline
\end{tabular}

a $10 \%$ weight loss temperature observed by TG. polymer $9 \mathbf{c}$ is shown in Figure 1 . The polymer showed a $10 \%$ weight loss in air and under nitrogen at 445 and $450^{\circ} \mathrm{C}$, respectively. These data are summarized in Table IV. The good thermal stability of the aromatic poly(oxadiazole)s was comparable to that reported in the literature. ${ }^{1 \mathrm{f}, 10}$

Acknowledgement. The authors are indebted to Mr. Takeyoshi Takahashi for performing the elemental analyses.

\section{REFERENCES}

1. a) M. Ueda and T. Kano, Macromol. Chem. Rapid Commun., 5, 833 (1984); b) M. Ueda, M. Sato, and A. Mochizuki, Macromolecules, 18, 2723 (1985); c) M. Ueda, S. Yokote, and M. Sato, Polym. J., 18, 117 (1986); d) M. Ueda, H. Sugita, and M. Sato, J. Polym. Sci., Polym. Chem. Ed., 24, 1019 (1986); e) M. Ueda and M. Sato, Macromolecules, 20, 2675 (1987); f) M. Ueda and H. Sugita, J. Polym. Sci., A, 26, 159 (1988).

2. a) M. Saga and T. Shono, J. Polym. Sci., B, 4, 869 (1966); b) V. V. Korshak, Ye. S. Krongauz, and A. L. Rusanov, Izv. Akad. Nauk SSR, Ser. Khim., 11, 2663 (1968); c) P. M. Hergenrother, Macromolecules, 3, 10 (1970).

3. P. E. Eaton and G. R. Carlson, J. Org. Chem., 38, 4071 (1973).

4. a) E. C. Taylor and S. F. Martin, J. Org. Chem., 3958 (1972).

b) T. Shono, M. Izumi, S. Matsumura, and N. Asano, Japan Patent, 68-15,992 (July 5, 1968).

5. S. Nishizaki and A. Fukami, Kogyo Kagaku Zasshi, 70, 1607 (1967).

6. R. C. Evers, F. E. Arnold, and T. E. Helminiak, Macromolecules, 14, 925 (1981).

7. R. Stolle, J. Prakt. Chem., 69, 157 (1904).

8. a) J. A. Bladin, Chem. Ber., 22, 3114 (1889); b) E. Bamberger and P. Degruyter, Chem. Ber., 26, 2385 (1893); c) A. Pinner, Ann. Chem., 297, 221 (1897); d) E. L. Rinnan, Chem. Ber., 30, 1193 (1897).

9. R. Huisgen, J. Sauer, H. Y. Strum, and J. H. Markgraf, Chem. Ber., 93, 2105 (1960).

10. A. H. Frazer, W. Sweeny, and F. T. Wallenberger, $J$. Polym. Sci., A, 2, 1157 (1964). 